Portland State University

PDXScholar

\title{
Collective Intervention: an Analysis of the Political Issues Regarding Secession, Self-Determination, and Sovereignty in the Republic of Kosovo
}

Benjamin Werthan

Portland State University

Follow this and additional works at: https://pdxscholar.library.pdx.edu/honorstheses

\section{Let us know how access to this document benefits you.}

Recommended Citation

Werthan, Benjamin, "Collective Intervention: an Analysis of the Political Issues Regarding Secession, SelfDetermination, and Sovereignty in the Republic of Kosovo" (2016). University Honors Theses. Paper 219. https://doi.org/10.15760/honors.216

This Thesis is brought to you for free and open access. It has been accepted for inclusion in University Honors Theses by an authorized administrator of PDXScholar. Please contact us if we can make this document more accessible: pdxscholar@pdx.edu. 


\title{
Collective Intervention: An Analysis of the political Issues regarding Secession, Self- Determination, and Sovereignty in the Republic of Kosovo.
}

\author{
By: \\ Benjamin Werthan
}

An undergraduate honors thesis submitted in partial fulfillment of the

requirements for the degree of
Bachelor of Science
In
University Honors
And
Economics
Thesis Advisor:
David Kinsella,
Portland State University Professor 


\section{Table of Contents}

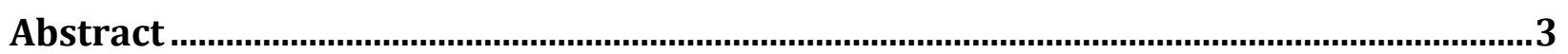

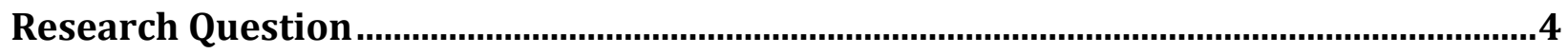

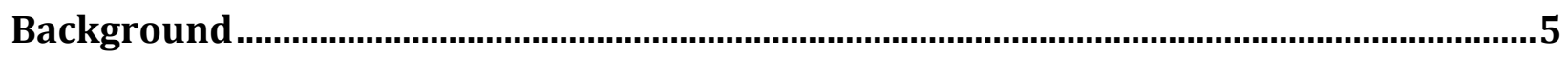

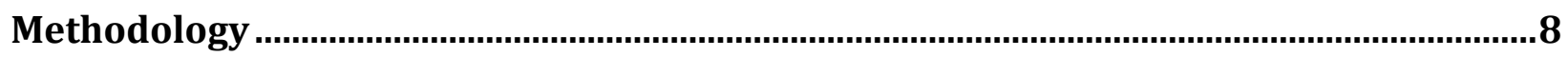

Literature Review ................................................................................................................ 11

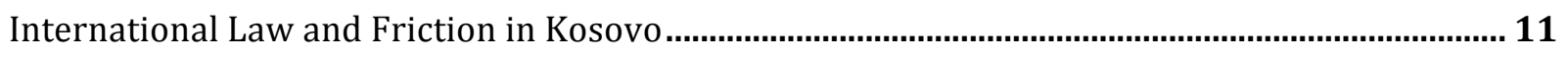

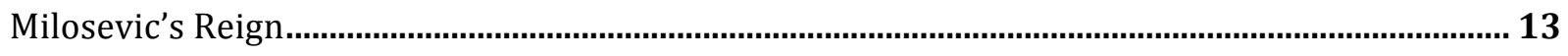

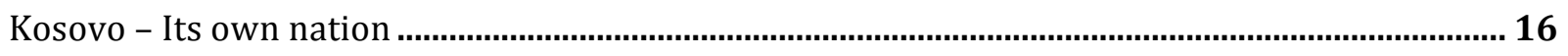

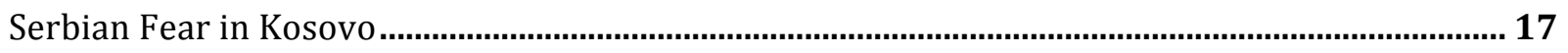

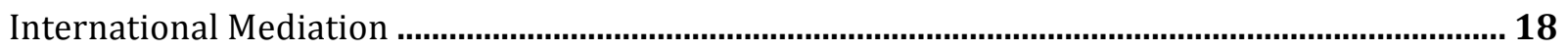

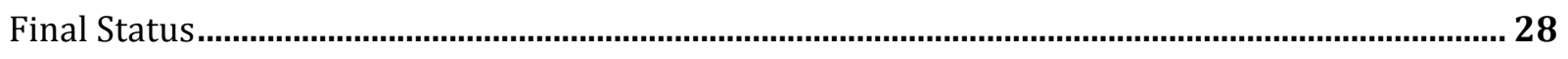

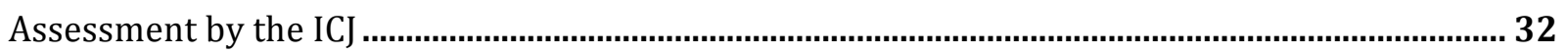

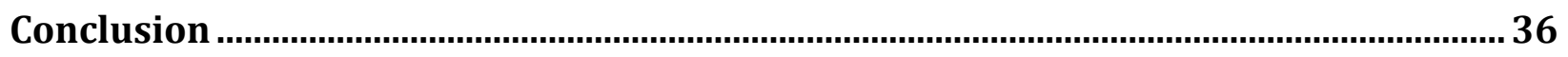

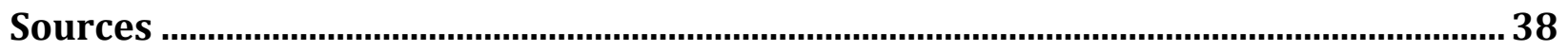




\begin{abstract}
:
In 2008, the Republic of Kosovo, after years of war and internal conflicts between the ethnic Albanians and Serbians who lived in the territory, finally received status as an independent state. The process was long and even after declaring independence the Republic still had to fight for such recognition. This thesis explores that process, starting with the years prior to the Yugoslav Wars, through the Republic of Kosovo's Declaration of Independence and the subsequent International Court of Justice advisory opinion. The purpose of this thesis is to explore the concepts of self-determination and state sovereignty with regard to the actions taken by international organizations, NATO and the United Nations, while also determining the legitimacy of those actions when scrutinized under International law. The findings of this literature review lead to the conclusion that the intervention done by NATO and the United Nations, while hindering on Serbia's sovereignty, stabilized the region and led to the end of massive human rights violations.
\end{abstract}




\section{Research Question:}

How has the intercession by the United Nations and NATO, in the Republic of Kosovo, impacted the execution of the principle of self-determination, and the subsequent formation of this new sovereign state? 


\section{Background:}

The situation in the newly independent Republic of Kosovo was a dire one. On one side of the Kosovo War were the Kosovar Albanians. This group made up almost $88 \%$ of the total population of the territory of Kosovo. ${ }^{1}$ On the other end you have the Serbs, who fought in accordance with the Federal Republic of Yugoslavia (FRY) population, the group whom attempted to be the main, legal successor to the Socialist Federal Republic of Yugoslavia (SFRY) after the disbandment of the latter, during the post-Yugoslav War era in 1992. At the time of the creation of the FRY, some states, such as the United States, refused to acknowledge this name and instead referred to the state as Serbia and Montenegro. ${ }^{2}$

The territories, which comprised the previous SFRY, were slowly separating into their own legal states, which caused great tension in the region. The new FRY, encompassed by Serbia and Montenegro, was determined to hold together what remained of their "kingdom," before multiple wars tore the region apart. Kosovo, which was still an autonomous (although not solely independent) province of the Socialist Republic of Serbia (SR Serbia), was determined to force the hand of their current government and seek representation that better embodied the people living within the territory (the aforementioned Kosovar Albanians). Upon this final decision to rebel and fight for Kosovo, the ethnic Albanians created the Kosovo Liberation Army (KLA) ${ }^{3}$ which was used as a force to separate from the FRY and seek sovereignty as its own independent state. The Kosovo Liberation Army was a paramilitary organization that sought the separation of Kosovo from Yugoslavia." ${ }^{\prime 4}$ At the time of the creation of the KLA, there was overwhelming support coming from the Kosovar Albanians who lived in the territory that wanted to separate and 
become an independent sovereign state; $99 \%$ support for a referendum of independence within the SFRY, with $87 \%$ participation of the population partaking in the poll. ${ }^{5}$

The main issue surrounding the independence of the territory of Kosovo was the tension between two ethnic groups: Serbians, who were the largest ethnic minority group, and the Kosovar Albanians, who made up the ethnic majority and overwhelmingly outnumbered the Serb population. The population of SR Serbia and their leader, Slobodan Milosevic, backed the Serbian population in Kosovo. Milosevic led SR Serbia as president before becoming the president of the FRY during the height of terror and tension within the state. His human rights violations, by way of the Yugoslav Army and Serbian police, towards the people within the territory were the main cause for the Kosovar Albanian population to seek independence and sovereignty. On the other hand, the kidnappings, massacres, public destruction of property, including churches and cemeteries and summary executions performed by the KLA, among other crimes, were the most pressing concerns for the Serbian population to fear Kosovar Albanian takeover and subsequent independence of Kosovo. ${ }^{6}$ The only problem left for the rebel group was gaining enough support from the international community to help their efforts to restore human rights for the people and to provide safety for all within the war zone.

This thesis fits in the academic field of two topics; international law and international relations. On one hand, the study of international law plays a part in fully understanding the scope of the disagreement and subsequent rebellion within the territory of Kosovo. The right of self-determination and, even more specifically, the right of external self-determination are the center of attention in this narrative. This thesis, comprised as a literature review, will describe and summarize in detail this right, and how other 
international authorities, such as the North Atlantic Treaty Organization (NATO) and the United Nations (UN), influenced such decisions. The analysis of the right of selfdetermination and what role those international authorities played is where the study of international relations is related to this thesis. The study of International relations is an interdisciplinary subject that takes into account many factors, such as economics, political science, history, foreign languages and others. ${ }^{7}$ Both of these academic fields formed the framework and starting point for this analysis.

In 1945, the United Nations was formed. The cause of the organization's formation was to be a protection against the possibility of, and hopes of preventing a third world war. Nations would join and voluntarily submit some of their sovereign power to the international organization under the belief that presenting a united front against the threats to, "peace and security, climate change, sustainable development, human rights, disarmament, terrorism, humanitarian and health emergencies, gender equality, governance, food production and more" would subside threats more efficiently and effectively. ${ }^{8}$ The term "United Nations" was coined by US President Franklin D. Roosevelt in 1942 and provided the basis for its formation ${ }^{9}$, even though some of the threats of the $21^{\text {st }}$ century, listed above, were unknown at the time, specifically climate change.

The organization has had 193 members officially join, with two other nations acting solely in observation. ${ }^{10}$ With this large number of members and these nations having many contrasting interests, the UN has provided a chance to form dialogue between nations and laid out a stage for negotiations to be had, in order to prevent potentially hostile communications from becoming dangerous and solved in a diplomatic manner. As part of the introduction of the UN, there was the creation of the UN Charter, which has acted as a 
treaty among all member states who have joined. A main section of the Charter discusses the rights of self-determination among each nation state, which is essential in the understanding of the rights of sovereign states. In its most simplistic form, selfdetermination is the, "principle of equal rights and fair equality of opportunity, [where people] have the right to freely choose their sovereignty and international political status with no external compulsion or interference."11

The North Atlantic Treaty Organization (NATO) is comprised of 28 member states, all of which are also members of the UN. The organization's stated purpose is one of freedom and security for its members, resolved through political and military means. ${ }^{12}$ The efforts of NATO, to show states of different values as united for a common goal, which is to resolve disputes peacefully and diplomatically, are equal to that of the UN. NATO, also like the UN, commits to resolving issues peacefully during times of negotiations, but will provide a strong military front if necessary. This quick look into the UN and NATO, by stating their purposes and ultimate goals, is to provide a background from where these international organizations were coming from with regard to the situation in Kosovo that will be further explained and analyzed throughout this essay.

This thesis explores the dire moments in the history, and eventual establishment of the Republic of Kosovo and the importance that the two international organizations, NATO and the UN, played in stabilizing this region in southeast Europe. The ethnic tension and violence between a huge part of the population of a sovereign state and one of its own provinces, massive human rights violations such as ethnic cleansing and mass murders, and corrupt government officials provided the context and importance of this issue within the global community. This context, it is contended throughout the paper, explains that the 
international organizations properly intervened and intruded on the disputes that were taking place within the borders of a sovereign state, an issue that the global community has had difficulty dealing with in the past. Protocols were broken in the process of solving the issues in Kosovo and this thesis is an analysis and justification as to why breaking the rules was a necessary step to ending the civil strife and civilian deaths. 


\section{Methodology:}

The process in which I undertook this thesis was that of a long literature review. I gathered up many sources (journal articles, newspaper articles, official court documents, government websites, etc.) to create an overall evaluation of the work that has been done on this topic. From these sources, I created this work as a conclusion of taking all these accounts and works as a whole. These sources covered many areas that are relevant to my topic. These areas include official documents from the United Nations, such as the 'Interim Agreement for Peace and Self-Government in Kosovo' for example, and the Republic of Kosovo, in addition to official transcripts of the International Court of Justice's oral arguments and advisory opinion. I also used many academic journal articles and other publications that examined topics such as mine or were closely related, such as 'UNMIK in Kosovo: Struggling with Uncertainty' by Jürgen Friedrich and 'NATO's Humanitarian War over Kosovo' by Adam Roberts. My last main sources came from government websites that provided definitions or clarifications on other primary source articles.

Most of my sources were found online from Portland State databases. There were a couple books that played a role in my research. International Law, by Vaughn Low, was a tremendous source I was able to use in helping research the topic of self-determination as a whole even though the source was not cited in this work. The databases I used most were Google Scholar, JSTOR, Academic Search Premier, and Columbia International Affairs Online (CIAO). 


\section{Literature Review:}

\section{International Law and friction in Kosovo}

International law is the external "governing force" keeping the international community in order. There is no realm possible for International law to require states to abide by its rules (without a single hegemonic power), which makes the concept tricky to understand in terms of solidifying its standing on the international stage. In addition, international law has been a social function since before both World Wars and is nearly impossible to enforce. Philip Allott, in his article "The Concept of International Law," stated a threefold task I believe succinctly articulates the premise of law.13 First he states "law carries the structures and systems of a society through time." Secondly, "law inserts the common interest of society into the behavior of society members." And lastly, "law establishes possible futures for society, in accordance with societies theories, values, and purposes." Applying these facets and attributes of Allott's definition of what law is, to the global stage, presents obvious complications because each state has its own culture, ethics, morals and values. If there is disconnect between the people and the government (who creates and enforces the laws) then there will be civil strife in those areas. In Kosovo, there was a tremendous amount of contention due to a government repressing and violating the human rights of its people and the backlash from those violations.

One of the biggest disconnects in Kosovo was that the laws did not line up with what a majority of the population felt was right or believed to be morally correct. ${ }^{14}$ Throughout the years, before the Yugoslav Wars, Kosovo's Albanian population continued to rise dramatically, reaching almost $90 \%$ of the population, while the Serb population in the territory continued to fall, hitting $8 \%$ as many of them left the area. ${ }^{15}$ Even as this trend 
continued, Kosovar Albanians encountered constant discrimination, especially once Slobodan Milosevic took control of Serbia and subsequently took over control of the Socialist Autonomous Province of Kosovo in $1989 .{ }^{16}$ Once Milosevic gained power in Serbia, Kosovo became under fire even more so. Milosevic was particularly resilient towards his dislike of Kosovo because of the fact that Kosovo, one of Serbia's territories constantly voted against Serbia in their federal government. ${ }^{17}$ In 1974 , Yugoslavia amended its constitution and gave sovereign control to the republics of Slovenia, Croatia, BosniaHerzegovina, Montenegro, and Macedonia over each of their respective territories. ${ }^{18}$ Serbia, however, did not receive such sovereignty, as the province of Kosovo was given prerogatives equal to that of a republic, including the right to have its own administration, assembly and judiciary. ${ }^{19}$ The reason for Kosovo being given special status began with the formation of Yugoslavia at the end of World War II, in 1945 and the dispute between Albania and Serbia. Both states thought they had the right over the territory and have for years. Albania's claim relied on them being the "original inhabitants" of the land, as they were the descendants of the ancient Illyrians. ${ }^{20}$ Serbia's claim was based on their insistence that Kosovo was positioned in the "middle of its medieval kingdoms" and that no Albanians lived amongst them. ${ }^{21}$ Serbia did eventually gain control of the territory but the dispute caused trouble for Yugoslavia, as Albanian uprisings throughout the time period of 1945 until 1974 continued.22 These troubles lasted up until the 1974 Constitutional adoption when Kosovo gained autonomous status. Milosevic, from the moment he took office, sought out to give rise to national Serbian pride throughout both Serbia and for those in the territory of Kosovo. ${ }^{23}$ The rationale for the great heights of Milosevic's Serbian nationalistic pride very easily could have stemmed from Serbia's loss of territorial autonomy from the 
1974 Yugoslavian Constitution. His main goal was to reduce the Albanian population to "second class citizens" 24 as can be seen by his usage of ethnic and religious hatred to gain political power.

\section{Milosevic's Reign}

Due to the tremendous height of Albanian nationalism that had been continuing to rise in Kosovo, and the discrimination against the Serbs (by the local Albanians), Milosevic took matters into his own hands. In the early months of 1989, he led the charge of Serbian nationalism back to center stage, and the first thing he needed to do: amend the Serbian Constitution. ${ }^{25}$ Yugoslavia's National Assembly allowed the amendments to take place, stating that the previous (1974) Yugoslavian Constitutional changes were actually unconstitutional due to the fact that, post World War II, the goal of Yugoslavia was to provide a stability in the region by forming a Yugoslavia with six equal republics. ${ }^{26}$ Because of Serbia's lack of sovereign control over its territories, this was not the case. The Yugoslavian National Assembly stated that the 1974 Constitutional changes violated the country's Anti-Fascist Council as well. ${ }^{27}$ In these 1989 Constitutional amendments, it was decided that: Serbian laws overruled and took precedent over all provincial laws, Serbia controlled judicial appointments and firings, provincial economic and educational policies were to be coordinated with Serbia, and lastly, and quite possibly most importantly, the "provinces lost their diplomatic role, military powers and much of their police power."28 Kosovo could no longer veto changes to the Serbian Constitution and were in a substantial disadvantage in almost every possible way.

Milosevic was not quite done with this matter however as before the Constitutional amendments could occur, Kosovo's (and the other at-the-time-still-autonomous provinces) 
Assembly had to pass the changes by a three-fourths majority. In what was a situation clearly stacked with threats and other forms of coercion against the people of Kosovo, the amendments were passed ${ }^{29}$ The clear coercion in the situation regarding control of the province of Kosovo was astronomically corrupt. First, there was no three-fourths majority decision, but the amendment passed anyways. ${ }^{30}$ Second, there was no quorum present at the assembly during time of voting. ${ }^{31}$ Thirdly, random security personnel were allowed to vote in addition to representatives from Belgrade receiving a vote and counting towards the "majority" decision (Belgrade, the capital of Serbia, is not located in Kosovo, and should not represent a vote). ${ }^{32}$ Fourth, voters were threatened if voting "no", while some votes were plainly not counted..$^{33}$ Lastly, the vote took place while Kosovo was announced being in a "state of exception/emergency" with disorder in the province and the mobilization of the military. ${ }^{34}$

Kosovo was, in fact, in a real state of emergency. During the time of the vote, major riots and protests began to take place, eventually placing the province in a state of martial law that continued for months after the vote. ${ }^{35}$ On June $28^{\text {th }}, 1989$ Milosevic gave his infamous Gazimestan speech in which he stated that the future of Serbia could be led by the possibility of "armed battles" to lead Serbian national development. ${ }^{36}$ The speech praises the passage of the new Constitution, stating, "Through the play of history and life, it seems as if Serbia has, precisely in this year, in 1989, regained its state and its dignity and thus has celebrated an event of the distant past which has a great historical and symbolic significance for its future." ${ }^{37}$ Many believe that this statement was the message he was trying to portray for the entire speech, essentially what its entire meaning was all about; that Serbia had suffered greatly in the past, which brought down national Serbian pride, 
and with the strengthening of the central role of Serbia (by weakening the province of Kosovo), they (pride of the people and strength of the government) would rise together to restore Serbia to its former glory. The speech was viewed as the turning point for Yugoslavia and ultimately was a seen as the beginning of the Yugoslav Wars. Milosevic played the emotions of his followers very effectively, knowing that he could use the message of Serbian pride to consolidate his power. Eventually, Slovenia, other surrounding states, as well as the Soviets and western European states began to take sides on the conflict.

While Milosevic was rallying up fellow Serbian followers, Kosovo was in an extremely vulnerable position. The people (mostly of Albanian ethnicity) wanted secession from Serbia. As a result the Kosovar Albanians began a non-violent uprising of civil disobedience with the goal being independence for Kosovo. ${ }^{38}$ In 1991, Kosovo declared its own independence, after the self-proclaimed Kosovo Parliament announced, by way of an independence referendum, that the new Republic of Kosovo would be known as an independent state and a republic of Yugoslavia. ${ }^{39}$ The Independence Referendum was a public vote that got a turnout of just over $87 \%$ of the population and resulted in $99.98 \%$ "yes" votes in favor of declaring independence. ${ }^{40}$ This should not be confused with the 2008 official declaration of independence, as the Republic of Kosovo (from 1991) was only recognized as independent by one other state: Albania. In 2000, after the end of the Kosovo War, the Republic of Kosovo officially disbanded and the United Nations Interim Administration Mission in Kosovo replaced its institutions. 


\section{Kosovo - Its own nation}

It is estimated that about $15 \%$ of the Kosovar Albanians were displaced prior to NATO intervention in 1998 (about 250,000 out of 1.6 million, although some estimates reach as high as 400,000). ${ }^{41}$ There were also thousands of deaths in the preceding months (about 1,500 according to the NATO website). ${ }^{42}$ Serbian police were the cause of many deaths to the Kosovar Albanian's. On the other side was the Kosovo Liberation Army (KLA) whom also contributed to many civilian casualties. With the creation of the KLA, which radicalized the Kosovar Albanian group, came the extreme responses and retaliation by the Serbian police and Yugoslavian Army. It has been said that Serbian nationalism and the actions they took only heightened Albanian nationalism to the extent that the sides were reaching points of extreme polarization in which there was no going back from. The Kosovar Albanian's were fighting for their lives and for independence, while the Serbian's were fighting for their lives and to keep sovereign control of their territory, one that has been described as the "heartland of Serbian history, culture and religion." ${ }^{43}$

Both Kosovar Albanians and Serbians had experienced extreme displacement caused by the fighting and constant danger. ${ }^{44}$ It wasn't until early 1998, not long after the Kosovo War had begun, that NATO and other international organizations began to take a stand in the fight. NATO officials were eager to end the violence and many were concerned with the total disregard for a diplomatic and peaceful end of the situation, mostly on the side of Milosevic. ${ }^{45}$ NATO's primary goal was to 'help to achieve a peaceful resolution of the crisis by contributing to the response of the international community. ${ }^{46}$ As the crisis continued into the middle and end of 1998, NATO decided on swift action to end the dispute and bring peace back to the region. Air strikes were called at which point Milosevic 
finally agreed on a cease-fire, which lasted until early 1999, when provocation from both sides resulted in excessive force by the Serbian police that heated up the violence once more..$^{47}$

\section{Serbian Fear in Kosovo}

While it is true that Milosevic instilled fear and a state of panic among the ethnic Albanians causing them to want to secede, the Serbs also had reason to panic. The idea of Kosovo becoming independent did not bode well for the Serbs who lived in the territory. While the Yugoslav Army and Serbian police forces patrolled the streets (before the drawback post-NATO bombing), so too did the KLA. The practice of human rights violations was not just placed on the shoulders of the Serbian forces but also on the members of the Kosovo Liberation Army. There were over 200,000 Serbian people who were forced from their homes ${ }^{48}$ that also saw Serbian churches and schools burned to the ground. This massive amount of displaced persons is in fact ethnic cleansing, a human rights violation. While the ethnic Serbs had the backing of the Serbian government and Yugoslav Army, the sheer difference in the amount of people in the ethnic groups, even before the massive displacement took place, was huge. Combine this with the fact that the non-violent practices that the Kosovar Albanians took up were replaced with the aforementioned church and school burnings, in addition to mass murders of the Serbians, including children, and hostages that the KLA kept, meant that this was not a victimless circumstance on either side. ${ }^{49}$

Furthermore, reports surfaced that many members of the KLA were not just seeking independence for Kosovo but also sought out a concept known as "Greater Albania." 50 The Greater Albania movement, also known as the Ethnic Albania movement, dates back to 
1878 and encompasses the ideology to reclaim and reoccupy all of a lost homeland of Albania, to unify a territory that is for Albanians only. ${ }^{51}$ This movement incorporated a couple of essential requirements for Greater Albania to succeed. ${ }^{52}$ First, there must be a foreign intervention done by a Superpower country or organization. This was because Albanians were minority in the land they sought to gain control of, and the only way to take this land back was by war, which Albanians alone could not win. Second, ethnic groups must be targeted as the enemy. This target, created by supporters of the Greater Albania movement, would be comprised of those who oppressed Albanian victims. Finally, ethnic homogeneousness and the creation of an ethnically pure religion was essential. The entire basis for this ideology was to cleanse "Ethnic Albania" from all other ethnicities. This point was essential. It was for these reasons that the radicalized KLA was seen by some as a terrorist organization, one that Serbians in Kosovo experienced firsthand.

\section{International Mediation}

Throughout the 1990's and heading into 1998, the tension between the Kosovar Albanians and the Serbs was at its height. Both sides of the war, the Yugoslav Army plus Serbian police force on one side, and the KLA on the other had experienced and inflicted human rights violations directed towards the enemy. Fighting had lasted over a year with no end in sight. The UN Security Council had not passed any resolution that allowed intervention, but NATO proceeded anyways, by unilaterally ordering air raids in an attempt to gain control of the ground and demand a ceasefire to end all civil strife between the belligerents on both sides. On June 10, 1999, after 78 days, the air raid campaign by NATO forces were called to stop. ${ }^{33}$ On that same exact day the United Nations Security Council, by a 14 - 0 vote (with one abstention) passed UN Resolution 1244. Resolution 1244 
enumerated the objectives and functions of the Kosovo government and at the same time it stressed sovereignty and territorial integrity of the Federal Republic of Yugoslavia. ${ }^{54}$ One of the big problems facing the UN and NATO was regarding what they were going to do with the controlling government of Kosovo. Technically, the province of Kosovo was under the control of the Serbian government. However, with the people in the territory experiencing extreme violations of basic human rights, rights that are widely acknowledged by the international community, the international organizations couldn't stand by and allow the violations and hardships to continue.

Resolution 1244 seemed to present the UN as a mediator coming to negotiate a peaceful resolution to end the war rather than to take a position on external self determination. Although there is no specific definition of external self-determination, the concept encompasses a standard of customary human rights, and the right of an appropriate body to enforce those standards. ${ }^{55}$ These standards were laid out by the UN's Universal Declaration of Human Rights. The criterions that this declaration lays out include; all human beings are born free and equal in dignity and rights, everyone has the right to life, liberty and security of person, no one shall be held in slavery or servitude, no one shall be subjected to torture or to cruel, inhuman or degrading treatment or punishment, and everyone has the right to recognition everywhere as a person before the law, to name only the first six articles. ${ }^{56}$ If these standards are not met, then "groups of people" would be justified in using this right.

When it comes to external self-determination, Resolution 1244 states that it wont get involved in the territory dispute regarding minority human rights violations and whether or not those violations justify seccession by reaffirming the FRY's territorial 
integrity ${ }^{57}$ According to a 1996 report done by the United States Institute of Peace, after a discussion with the U.S Department of State's Policy Planning, the United States has faced pressure regarding this exact situation in other circumstances. The Report said that no matter what the specific scenario is:

The rights to self determination must be separated from the right to secession and the establishment of independent statehood, with the understanding that there are intermediate categories short of statehood that can address a minority group's interests and aspirations...Human rights violations are easy to condemn; the dilemma is whether they justify the persecuted group's secession from the state, a conclusion the international community is largely unwilling to draw. ${ }^{58}$

Resolution 1244 only laid out the plan that the international organizations would carry out. The specific entity that led the groundwork in Kosovo was the United Nations Interim Administration Mission in Kosovo (UNMIK as it is referenced). UNMIK was founded on the ground of four basic pillars (or principles). Each of these pillars were based on tasks defined in Resolution 1244, which contained an obligation of the FRY to end all violence, withdraw all military, police and paramilitary forces from Kosovo, called for the KLA to end all violent action and to demilitarize, and lastly established an "international civil presence," what would later be know as UNMIK. ${ }^{59}$ Pillars 1 and 2, Police and Justice Administration and Civil Administration respectively, were led by the United Nations; Pillar 3, Democratization and Institution Building, were led by the Leadership of the organization for security and cooperation in Europe (OSCE); while Pillar 4, Restructuring the Economy and Infrastructure, was carried out by the European Union (EU). ${ }^{60}$ 
The UNMIK's purpose, as laid out by Resolution 1244, was to play the role of interim government while altercations between Serbia and the majority population of Kosovo subsided as NATO and the Kosovo Force (KFOR) played the roles of traditional peacekeepers. ${ }^{61}$ The Kosovo Force had the responsibility of maintaining the safety and protection of the UNMIK workers as well as other international organization workers. ${ }^{62}$ They were also given three tasks in addition to peacekeeping. Those tasks were to deter new hostilities (peacekeeping), ensure that refugees can return safely, ensure humanitarian aid can be delivered, and demining/monitoring the border. ${ }^{63}$ The final goal of the UNMIK was always to establish and develop a fully functioning, autonomous, and self governing Kosovo, which could provide justice and security for the people. ${ }^{64}$ This was supposed to be done all while keeping Serbia's sovereignty intact, because, as previously stated, the UN did not want to address the situation of sovereignty and external selfdetermination. The "final status" as it was called, would be determined in the future by the legislative process, once Kosovo had a stable government. ${ }^{65}$

Some question the legality of the UN and NATO intervention in Kosovo, wondering how these international organizations had the right to place themselves in the middle of this intrastate war. In the UN Charter (governing powers and principles of the UN), Article 1 Section 2, it states, "The purposes of the United Nations are to develop friendly relations among nations based on respect for the principle of equal rights and self-determination of peoples, and to take other appropriate measures to strengthen universal peace."66 The most basic founding principle of the United Nations was to bring about world peace and security by uniting nations. When maintaining peace is subject to falsity then the UN must act, even if just a small region in southeast Europe is in question. 
The events that took place in Kosovo have also long been discussed as being essential to the creation of the Responsibility to Protect. Responsibility to Protect, or R2P as it is sometimes referred, is the proposed custom that sovereignty is not an absolute right and that state sovereignty is relinquished when that state, "fails to protect its population from genocide, war crimes, ethnic cleansing, and other crimes against humanity." 67 The Responsibility to Protect was adopted during the 2005 World Summit (where the largest number of heads of state and government convened in one place in the history of the UN) but it originated from the likes of then Assistant-Secretary General of the UN Department for Peacekeeping Operations Kofi Annan ${ }^{68}$ as well as a Canadian established commission called the International Commission on Intervention and State Sovereignty (ICISS). ${ }^{69}$ The need for an adoption of such a custom was based in the failure of the international community to mediate during the catastrophe that occurred in Rwanda in 1994. In review of the UN's failure to remedy the Rwandan Genocide, Annan based his criticism on the fact that there was no internationally accepted process to intervene in another country's domestic issues.

There was a way, however, and it was by a process called Humanitarian Intervention, which is the course by which a state using military force against another state, publically declares that the aim of said military force is to end human rights violations being "perpetrated by the state against which [the military force] is directed,"70 but has also been defined less strictly so as to include "non forcible methods...to alleviate mass human suffering within sovereign borders." ${ }^{" 1}$ Humanitarian Intervention is a heavily criticized method of peacekeeping because it directly goes against a main principle of the UN, which is that states are sovereign within their boundaries, according to the UN Charter 
Article 2(4) $\cdot{ }^{72}$ However, the UN's main focus is, in fact, maintaining peace and security. Chapter VII, Article 41 requires the UN to consider non military action first and foremost to calm breaches of peace, and, only if those peacekeeping provisions are deemed insufficient to restoring peace may the UN authorize military force, according to Article $42.7^{73}$ Supporters of Humanitarian Intervention look at the use of military force as a justifiable means to an end. They place the importance of ending human rights violations ahead of state sovereignty. Critics of this type of intervention, however, place tremendous weight on viewing forced intervention as one entity imposing its will on another, and view this force as lacking legal sanction as well as the fact that it would be too simple to ambiguously deploy this method.

Humanitarian Intervention and Responsibility to Protect, while they each seek the same solution, to end mass human rights violations, differ in a key way. Humanitarian Intervention would occur by way of a resolution that is passed by the UN Security Council, including approval from all five permanent members; the United States, the United Kingdom, China, Russian Federation, and France. If one of those five members were to veto a resolution, for whatever the rationale may be (which is within their right as a permanent member), then no intervention will transpire. If a resolution is passed then the state that is being intervened upon loses sovereignty of its borders as the intervention proceeds and peacekeeping forces enter the state. Responsibility to Protect, on the other hand, is a preventative measure that stresses the responsibility of the states to protect populations at risk. $^{74}$

In this sense, Humanitarian Intervention accepts the right to intervene in order to end the abuses by the violating state, while Responsibility to Protect transfers the focus 
towards the best interests of the victims. It is also here where the two processes converge: as both recognize that state sovereignty is not an absolute right and therefore can be infringed upon. Where Humanitarian Intervention is solely military action, Responsibility to protect uses military intervention as a last resort that is only taken if a state does not uphold its responsibility. This is the very reason why Responsibility to Protect is the preferred practice by the UN. Responsibility to Protect pursues the foundational causes of the four mass atrocity crimes that breach the peace, and then if action is required, the UN will step in. Responsibility to Protect is the essence of the UN, to allow states to remedy their own problems first, and keep territorial integrity, before imposing their will if the situation in the state and region is dire enough to cause the UN to break one of its own guiding principles, that of state sovereignty.

It was the initial surge by NATO, and the bombings done by NATO forces that furthered the question of state sovereignty. In this time period, pre-Responsibility to Protect, the recognition of territorial integrity was prohibitive. As discussed in the previous paragraphs, Humanitarian Intervention was seen as inhibiting on a states right to act freely within its borders. NATO decided to engage with Kosovo because, after the breakdown of negotiations to a ceasefire between KLA and the Yugoslavian Army/Serbian Police, they realized that the only way to end the civil strife was to deploy military forces. ${ }^{75}$ The ceasefire, which was initiated by UN Security Council Resolution 1199, did not hold ground as the agreed upon military count for Yugoslav forces deployed in Kosovo was breached and provocations on behalf of both sides led to the fighting being resumed. ${ }^{76}$ NATO had agreed once before to call off planned air strikes after a promise of withdrawal of Serbian 
police and the Yugoslavian army in Kosovo ${ }^{77}$ and this time around, NATO did not make the same mistake.

NATO's involvement without UN Security Council authorization and without a UN Resolution in place was disconcerting, in a sense, because the practices stood on no legal framework. NATO's goals were to implement UN Security Council resolutions without UN Security Council authorization..$^{78}$ Without UN authorization, NATO was officially not partaking in Humanitarian Intervention but instead was infringing on Serbia's territory unilaterally, even if for a just cause. The "problem" with this situation was that, after the bombings ended (and granted, there were upwards of 2,500 civilians who died, as well as a number estimated north of 12,000 who were injured by the 78 days of bombings ${ }^{79}$ ) NATO was able to provide stability and security to the people in Kosovo and yet was doing it by breaking International law.

In addition, NATO was not able to fall back on their founding Charter as valid reasoning to intervene in the first place. Under article 5 of NATO's Charter, which outlines collective defensive action that can be taken, it states that, "the principle of self defense is at the very heart of NATO's founding treaty. It remains a unique and enduring principle that binds its members together, committing them to protect each other and setting a spirit of solidarity." 80 The biggest disconnect with the actions taken by NATO, even for a just cause, and the self defense article of their Charter, was that Serbia was not a NATO member (and obviously neither was Kosovo) and therefore NATO's actions were not based on the collective self defense of a treaty member. It was the actions of NATO that did usurp on Serbia's sovereignty, but these actions were also able to gain control of the violence 
between two warring sides. The fact that NATO operated on its own authorization will always keep the positive outcomes of their actions under scrutinized light.

Because this conflict was purely domestic, it makes answering the inquiry into the legality of the process much harder to rationalize, especially when the plan for peace involves the takeover and intervention of a sovereign state. Article 2 Section 7 of the UN Charter addresses this complexity by stating, "Nothing contained in the present Charter shall authorize the United Nations to intervene in matters which are essentially within the domestic jurisdiction of any state or shall require the members to submit such matters to settlement under the present Charter; but this principle shall not prejudice the application of enforcement measures under Chapter VII." ${ }^{81}$ This is the exact dilemma the UN and NATO were facing, as state sovereignty is a central principle for UN. What the UN Charter outlines is that states are very sovereign entities. Within borders, states can do almost anything they want. If peace is disrupted though, then a state will have issues with the UN.

Even though Kosovo is a province of a sovereign state, Serbia, meaning that this issue was intrastate, international organizations (such as NATO and the UN) sought out an end to the serious human rights violations. Clearly the peace had been breached in Kosovo and their reigning government was the center of the problem. Again, the UN in 'The Universal Declaration of Human Rights', which was adopted by the UN General Assembly on December 10, 1948, has outlined basic human rights. ${ }^{82}$ Here are articles 1-8, directly from the declaration itself:

Article 1 - All human beings are born free and equal in dignity and rights Article 2 - Everyone is entitled to all rights and freedoms set forth in this Declaration without distinction of any kind

Article 3 - Everyone has the right to life, liberty and security of person Article 4 - No one shall be held in slavery or servitude; slavery and the slave trade shall be prohibited in all their forms. 
Article 5 - No one shall be subjected to torture or to cruel, inhuman or degrading treatment or punishment

Article 6 - Everyone has the right to recognition everywhere as a person before the law.

Article 7 - All are equal before the law and are entitled without any discrimination to equal protection of the law. All are entitled to equal protection against any discrimination in violation of this Declaration and against any incitement to such discrimination.

Article 8 - Everyone has the right to an effective remedy by the competent national tribunals for acts violating the fundamental rights granted him by the constitution or by law

There are conflicting reviews on this matter, but it is my belief that the response from NATO and the UN was an action that was absolutely afforded to the Kosovar Albanians. This group of people was experiencing discrimination by their own government. There was no adequate power that those discriminated against could fall back on, except for international organizations, whose fundamental goals and principles were that which could end the suffering and provide security and peace that had been missing in the region for decades. The Universal Declaration of Human Rights, article 10, does afford a remedy directed towards those whose rights are taken, by way of a "fair and public hearing by an independent and impartial tribunal, in the determination of his rights and obligations, and of any criminal charges against him." ${ }^{83}$ The problem with the remedy, mentioned by article 10 , is that without intervention from an outside source, no violator would ever get to a hearing in the first place. This could very well be a problem for all circumstances of mass human rights violations, and if that is the case, new remedies should be provided that do allow the international community to intervene.

This war occurring in Kosovo, that caused the subsequent intervention by NATO and the UN, was the basis in which entry by these organizations would be justified. The entire process, starting with the creation and adoption of Resolution 1244 and the ensuing 
UNMIK government takeover, was meant as intervention to end the human rights violations, first and foremost. On the very first page of Resolution 1244 it is stated, "Determined to resolve the grave humanitarian situation in Kosovo, Federal Republic of Yugoslavia and to provide for the safe and free return of all refugees and displaced persons to their homes." ${ }^{84}$ This determination is followed up with, "Condemning all acts of violence against the Kosovo Population as well as all terrorists acts by any party." 85 These goals provide clear justification for the international communities response.

The arguments that NATO and the UN were simply exerting their power and influence on an unwilling nation do not hold much weight. There have been prior conflicts, both inter- and intra-state, that have resulted in force being taken against independent nations, sometimes for motives in which are not openly admitted (see: US invasion in Iraq). Most of those situations involve outward threats upon which action is taken. In the instance of the Kosovo War, there were no threats made to a state that the UN needed to act on but rather severe human rights violations that interfered with a main principle of international law. The conflict was disturbing the region and the international organizations knew they needed to intervene. ${ }^{86}$

\section{Final Status}

In situations regarding discrimination towards a "group of peoples" where human rights violations occur, there are remedies, such as exercising ones right of selfdetermination, available to end the violence and repression. The term "group of peoples" is commonly defined as "a group of people living in a delimited territory which possesses and is closely connected by a distinct history, language or other cultural attributes, and which is 
striving to preserve these characteristics. ${ }^{87}$ Kosovar Albanians meet the criteria as right holders in the situation they were experiencing in Kosovo.

Opponents to the idea of external self-determination wonder why the Kosovar Albanians are legally entitled to the exercise of their right of self-determination in this instance. Kosovo's exercise of this right does entail an extreme circumstance because the government of Kosovo's own sovereign state was the party committing the heinous crimes. Their only option was secession. Going back to being an autonomous province under Serbia's control, as they were prior to 1989 when Milosevic took over, was not an option. The unification of the two territories had not worked previously and after the amount of death, displacement of people, and other actions of violence and human rights violations, that each party participated in, sealed the fate that there was no going back to the way things were. As stated previously, the 1974 Yugoslavian Constitution had even given Kosovo what amounted to the same rights that Serbia had as a republic in the SFRY before Serbia took those rights were taken away. It is my belief that if Kosovo was forced to remain as an autonomous province of Serbia, the Kosovar Albanians, who still made up an overwhelming majority of the population and who wanted independence before the war even began, would absolutely still want independence. Luis Cabrera, in his book "Global Governance, Global Government: Institutional Visions for an Evolving World Systems" states:

A commitment to preventing human rights violations by one's own government makes the involvement of international institutions necessary. We often think of international human rights institutions as a means for certain countries to improve the human rights record of other countries. But international human rights institutions also help 
democracies fulfill their own constitutional commitments. They complete the domestic constitutional order. ${ }^{88}$

The Kosovar Albanians were faced with seeking secession or remaining under sovereign control of Serbia, and a government that represses entire ethnic groups. This was a situation that was extreme enough to warrant a declaration of independence.

The external right of self-determination has been used sparingly in the past and it should continue to only be used in extreme circumstances where there is no future arrangement that could peacefully end the violence. This is why the situation in Kosovo is an instance where secession should be approved. It is important to, again, acknowledge that the international organizations did not intervene so as to lead to this end result of secession. They have directly stated (in Resolution 1244) that the final future status was not going to be determined by the organizations themselves, but rather that the interim administration would help the people of Kosovo govern themselves. Essentially, selfgovernance, not necessarily as an independent state, but one that could support itself, was the final act that was laid out by the UNMIK and was therefore left up to the people of Kosovo to determine whether they should declare independence or not. Once a government was set up for Kosovo to govern themselves, they would be able to determine their own final status, otherwise known as self-determination.

Resolution 1244 and UNMIK have been criticized for a lack of clarity as to the final status of Kosovo. As discussed in the prior paragraphs, Kosovo was to determine its final status, with an overview done by the UN. On February 23, 1999 the UN attempted to achieve a more conclusive final status arrangement, for sometime in the future after Kosovo had a stable government, between Kosovo and Serbia known as the 'Interim 
Agreement for Peace and Self-Government in Kosovo.' 89 This agreement, known as the Rambouillet Agreement, was not signed by Serbia, but was given effect anyways by Resolution 1244. The agreement called for a new constitution for Kosovo that respects territorial integrity of the FRY (keeping intact Serbia's sovereignty, for the time being at least), while also "establishing the principles of democratic self-government for three years until final status of Kosovo is determined." 90 The agreement called for the "will of the people of Kosovo" to be one of the main principles that will define Kosovo's future status. ${ }^{91}$ Obviously, Serbia knew how the people would vote because of the majority population being Kosovar Albanians. However, the agreement, if it had been signed, also gave the FRY "competence over Kosovo" over the following areas; territorial integrity, maintaining a common market within the FRY, monetary policy, defense, foreign policy, customs services, federal taxation, and federal elections. ${ }^{92}$

On February 17, 2008 the Republic of Kosovo declared independence from SR Serbia and the Federal Republic of Yugoslavia. ${ }^{93}$ They did so acting outside of the UN Provisional Institutions of Self-Government. In the declaration, the people of Kosovo named the years of strife and violence as a disturbance that held up the advancement of their society. ${ }^{94}$ The Constitution of the Republic of Kosovo came into effect in June of 2008 and the state has been sovereign ever since. The day after declaring independence, the United States officially recognized the Republic of Kosovo as an independent state. ${ }^{95}$ Since the date of declaring independence, Kosovo has been officially recognized by 108 of 193 members of the UN, 23 of 28 members of the European Union, and 24 of 28 NATO member states. ${ }^{96}$ SR Serbia still does not officially recognize Kosovo as an independent state but the two nations have begun repairing and normalizing their relations. 


\section{Assessment by the ICJ}

Just over a month after Kosovo declared independence, Serbia called for the UN General Assembly to ask the International Court of Justice (ICJ) to determine a ruling on the legality of Kosovo's declaration of independence. ${ }^{97}$ The International Court of Justice is a ruling body, a "judicial organ," of the United Nations and was established as part of the United Nations Charter in $1945 .{ }^{98}$ They make rulings to settle legal disputes between nations according to accepted international law. The rulings brought down by the court are simply, just advisory opinions because nations have to submit themselves to the jurisdiction of the court meaning that whatever the ICJ decides is not legally binding. With regard to Kosovo, Serbia asked for an ICJ ruling as to whether Kosovo was in breach of international law by unilaterally declaring independence. The issue concerned many countries, with many being focused on whether Kosovo's unilateral actions, and possible approval by the ICJ, would set precedent for other provinces that were seeking to become independent states. For example, Catalonia in Spain and West Papua in Indonesia were both regions that secession was sought after, and would be affected by the ICJ advisory opinion.

In all, there were 35 countries that supplied written statements either for or against Kosovo's declaration of independence. ${ }^{99}$ Serbia was the first country to present its case to the Court. Their rationale for opposition to the declaration can be summarized by a couple of points. Principally, Kosovo, by unilaterally declaring independence, was directly challenging the international legal order based on the principles of sovereignty and territorial integrity. ${ }^{100}$ Kosovo was called the, "historical cradle of Serbia and constitutes one of the essential pillars of its identity" by Dušan Bataković, the Ambassador of Serbia to 
France, who represented Serbia at the hearing. ${ }^{101}$ Serbia argued that Kosovo's declaration was made by the temporary Kosovo government and was in violation of UN Resolution 1244 which guaranteed territorial integrity to the FRY; and that granting Kosovo's unilateral declaration would set dangerous precedent if other countries with UN administration concluded that the arrival of peacekeeping forces represented the first step in the secession of a region. ${ }^{102}$

Kosovo was next to present and was represented by Skënder Hyseni, their Foreign Minister. Kosovo's main argument was that Serbia gave up its right over the province of Kosovo because of Serbia's massive human rights violations towards the Kosovar Albanians. ${ }^{103}$ In making the argument that Serbia "gave up its right" to the province, Kosovo reasoned that it was Serbia's own doing that caused their territorial integrity to diminish as they failed in their "Responsibility to Protect." Kosovo also argued that the Serbian government would never be open to recognizing Kosovo as independent no matter how long negotiations lasted. This was demonstrated by Serbia's 1990 Constitutional changes which stated that Kosovo (and another Serbian province, Metohija) were both an integral part of the territory of Serbia, that it has the status of substantial autonomy within the sovereign state of Serbia. ${ }^{104}$

In addition to the two main parties in the case, there were 27 other countries to supply oral arguments. Albania, which was in full support of independence for Kosovo stated that there are, "two situations where a declaration of independence is a violation of international law...first, the situation of illegal intervention, and secondly, the violation of specific mandatory rules of international law."105 Albania went on to use the example of Northern Cyprus to show that Kosovo did not fit in with the first situation. Albania stated, 
"A particular telling example [of a situation of illegal intervention] is, of course, Northern Cyprus. No state except the one having intervened recognized the declaration of independence of Northern Cyrpus." ${ }^{106}$ This is compared to the multiple states that recognized Kosovo's declaration, just days (or in some instances, the very next day) after declaring, including the United States and the United Kingdom. ${ }^{107}$ Albania, throughout their oral arguments continued to insist that the declaration of independence was not the result of foreign intervention but rather was the consequence of human rights violations by the Serbian government that forced a secessionist movement by the majority population of Kosovo, and, therefore, this was a statement of self determination. ${ }^{108}$ The United States, in their statement recognizing Kosovo indicated Kosovo's situation was a "special case," according to then Secretary of State Condoleezza Rice, and that it "cannot be seen as a precedent for any other situation in the world today."109

Finally, on July 22, 2010 the ICJ delivered its advisory opinion on the matter. ${ }^{110}$ The opinion declared, by a 10-4 vote, that Kosovo did not break international law by unilaterally declaring independence for a few reasons. First, the ICJ stated that international law contains no applicable prohibition on declarations of independence.111 Second, the adoption of the declaration of independence did not violate UN Security Council Resolution 1244 because Resolution 1244 did not outline Kosovo's final status. Lastly, the declaration did not violate the UN Security Council's right to determine the final status of Kosovo because the Security Council had not previously reserved that right for itself in Resolution $1244 . .^{112}$ The President of the ICJ, Justice Hisashi Owada of Japan, further stated that the question asked of the Court to solve was one of legality. He explained that there was no international law preventing declarations of independence, which is what occurred 
in Kosovo. The concern that future provinces and territories would declare independence was not asked of the Court in this instance and in relation to this point, if future countries did in fact declare, that would also not be a legal question but rather a political one, in terms of each states recognition of future declarations.

Vice President of the ICJ, Justice Peter Tomka of Slovakia, provided a declaration to the opinion of the Court and reasoned that the Court should not have accepted to hear the case at all based on the fact that the General Assembly, the only body that can request a hearing from the ICJ, did not have "sufficient interest" in asking for a judgment. ${ }^{113}$ The lack of "sufficient interest" originates from the circumstance that the Security Council remained active in the situation of Kosovo and that fact alone should have prevented the General Assembly from requesting that any determination on Kosovo be made by the Court.114 Justice Abdul Koroma of Sierra Leone dissented to the opinion of the Court. His rationale was based on his interpretation of why the General Assembly wanted an ICJ advisory opinion, which was that he viewed the request as the "beginning of a process aimed at separating Kosovo from the State to which it belongs and creating a new State."115 Justice Koroma continued that the Court should not have looked at the author's (whom the court determined were representatives of the people of Kosovo rather than the UNMIK) intent but should have instead looked at, "the intent of the Security Council in Resolution 1244, which upholds the territorial integrity of the Federal Republic of Yugoslavia (Serbia). ${ }^{116}$ 


\section{Conclusion:}

The summation of my research led me to the conclusion that not only did the people of Kosovo have the right to exercise use of external self-determination, but that it was vital to the survival of the ethnic groups that faced discrimination, mainly the Kosovar Albanians. In order for their society to thrive and for their people to prosper, Kosovo needed to create separation between themselves and their repressor, Socialist Republic of Serbia.

The severe human rights violations, and sporadic dispersal of refugees in the neighboring states caused tremendous strife in the region, and thus created problems of keeping peace. Because of the issues regarding peace and security in the region, North Atlantic Treaty Organization (NATO) intervened in an attempt to bring both sides to a ceasefire and gain control of the ground. This control would allow the United Nations (UN) to pass Resolution 1244, which, in turn, established the United Nations Interim Administration Mission in Kosovo (UNMIK). UNMIK took over administrative duties of Kosovo in order to build a self-sustaining government for the people of Kosovo and to hopefully allow all dispersed persons to return safely to their homes.

The lack of communication and ability to work with one another, between the people and governments of Kosovo and Serbia, was the essential factor that led to instability in region. NATO, without consent from the UN Security Council, was able to provide a temporary stop to the violence on the streets and allowed the UNMIK to provide a bridge in the Kosovo government, from their prior destabilized establishment and assembly, to what is in place today. Today, Kosovo is lead by a Constitution that respects 
the rights of individuals and is recognized by many UN members around the world as a fully democratic, independent state. 


\section{Sources:}

${ }^{1}$ Simon Broughton; Mark Ellingham; Richard Trillo (1999). World music: the rough guide. Africa, Europe and the Middle East. Rough Guides. p. 5. ISBN 978-1-85828-635-8.

2 "Serbia - Constitutional Legal Foundations." StateUniversity.com. Net Industries, n.d. Web. 11 Jan. 2016.

${ }^{3}$ Friedrich, Jürgen. "UNMIK in Kosovo: Struggling with Uncertainty." Max Planck Yearbook of United Nations Law Online 9.1 (2005): 231. Web. 1 Nov. 2015.

4 "Liberating Kosovo: Coercive Diplomacy and U. S. Intervention". Belfer Center for Science and International Affairs. 2012. p. 69.

${ }^{5}$ Friedrich, pp. 231

6 "Human Rights Watch, Kosovo: Focus on Human Rights." Human Rights Watch, Kosovo: Focus on Human Rights. N.p., n.d. Web. 11 Jan. 2016.

7 "Politics, Economics, History, and Culture in the Modern World." Program in International Relations. Stanford University, n.d. Web. 7 Jan. 2016.

8 "Overview | United Nations." UN News Center. United Nations, n.d. Web. 13 Jan. 2016.

9 "History of the United Nations | United Nations." UN News Center. United Nations, n.d. Web. 13 Jan. 2016.

10 "Member States of the United Nations." UN News Center. United Nations, n.d. Web. 13 Jan. 2016.

11 United Nations, Charter of the United Nations, Chapter I, 24 October 1945, 1 UNTS

XVI, available at: http://www.refworld.org/docid/3ae6b3930.html [accessed 22 January 2016]

12 "Member Countries." What Is NATO? NATO, n.d. Web. 15 Jan. 2016. 
${ }^{13}$ Allott, Philip. "The Concept of International Law." The Role of Law in International Politics (2001): 31-32. Web. 11 Nov. 2015.

${ }^{14}$ Friedrich, pp. 231

${ }^{15}$ Broughton, Simon; Ellingham, Mark; Trillo, Richard (1999). World music: the rough guide. Africa, Europe and the Middle East. Rough Guides. pp. 5. ISBN 978-1-85828-635-8.

16 "Timeline of Kosovo History." World Library. World Public Library, n.d. Web. 11 Jan. 2016.

${ }^{17}$ Djilas, Aleksa. "A Profile of Slobodan Milosevic." Foreign Affairs. Council on Foreign Affairs, June 1993. Web. 13 Jan. 2016.

${ }^{18}$ Ibid.

${ }^{19}$ Independent International Commission on Kosovo. The Kosovo report: conflict, international response, lessons learned. New York, New York, USA: Oxford University Press, 2000. Pp. 35-36.

${ }^{20}$ Judah, Tim. "History, Bloody History." BBC News. BBC, 24 Mar. 1999. Web. 13 Jan. 2016. ${ }^{21}$ Ibid.

${ }^{22}$ Ibid.

${ }^{23}$ Djilas, Aleksa. "A Profile of Slobodan Milosevic." Foreign Affairs. Council on Foreign Affairs, June 1993. Web. 13 Jan. 2016.

${ }^{24}$ Ibid.

${ }^{25}$ Ibid.

26 "Context of 'March 23, 1989 and After: Kosovo Assembly Approves New Serbian Constitution; Unrest Follows'" History Commons. Creative Commons, n.d. Web. 13 Jan. 2016. ${ }^{27}$ Ibid. 
28 Ibid.

29 Ibid.

30 Ibid.

31 Ibid.

32 Ibid.

33 Ibid.

34 Ibid.

35 Ibid.

${ }^{36}$ Milosevic, Slobodan. "Milosevic Kosovo Field Speech 1989." SLOBODAN MILOSEVIC'S

1989 ST. VITUS DAY SPEECH. Slobodan-milosevic, n.d. Web. 13 Jan. 2016.

37 Ibid.

${ }^{38}$ Clark, Howard. Civil Resistance in Kosovo. London: Pluto, 2000. 46-49. Print

${ }^{39}$ Elsie, Robert. Historical Dictionary of Kosovo. Lanham, MD: Scarecrow, 2011. 88. Print.

40 "Kosovo (Yugoslavia), September 30, 1991: Independence." Sudd.Ch. Creative Commons, n.d. Web. 14 Jan. 2016

${ }^{41}$ Asst. Sec. of State Julia V. Taft, "US Government Humanitarian Assistance in Kosovo" [USIA Press Conference] (2 Oct. 1998)

42 "NATO's Role in Relation to the Conflict in Kosovo." NATO \& Kosovo: Historical Overview. NATO, 15 July 1999. Web. 13 Jan. 2016.

${ }^{43}$ Howe, Marvine. "EXODUS OF SERBIANS STIRS PROVINCE IN YUGOSLAVIA." The New York Times. The New York Times, 11 July 1982. Web. 8 Jan. 2016. 44 "NATO's Role in Relation to the Conflict in Kosovo." NATO \& Kosovo: Historical Overview. NATO, 15 July 1999. Web. 13 Jan. 2016. 
${ }^{45}$ Ibid.

${ }^{46}$ Ibid.

${ }^{47}$ Ibid.

${ }^{48}$ Stone, Brendan. "The U.S.-NATO Military Intervention in Kosovo." Global Research. Global Research, 29 Dec. 2005. Web. 16 Jan. 2016.

49 "World: Europe Serbs Highlight 'KLA Atrocity'" BBC News. BBC, 29 Aug. 1998. Web. 18 Jan. 2016.

${ }^{50}$ Savich, Carl. "Greater Albania: Explained." History of Kosovo and Metohija. Serbian Orthodox Diocese of Raska and Prixren, n.d. Web. 1 Feb. 2016. ${ }^{51}$ Ibid.

${ }^{52}$ Bissett, James. "War on Terrorism Skipped the KLA." Global Research. National Post, 13 Nov. 2001. Web. 24 Jan. 2016.

53 "NATO's Role in Relation to the Conflict in Kosovo." NATO \& Kosovo: Historical Overview. NATO, 15 July 1999. Web. 13 Jan. 2016.

${ }^{54}$ Friedrich, pp. 241

${ }^{55}$ Carley, Patricia. "A History of the Self Determination Concept." Self-determination: Sovereignty, Territorial Integrity, and the Right to Secession. Washington, DC (1550 M St., NW, Suite 700, Washington 20005-1708): U.S. Institute of Peace, 1996. 3. Print. ${ }^{56}$ The Universal Declaration of Human Rights. Rep. N.p.: United Nations, 1948. UN News Center. United Nations. Web. 18 Jan. 2016.

${ }^{57}$ UN Security Council, Security Council resolution 1244 (1999) [on the deployment of international civil and security presences in Kosovo], 10 June 1999, S/RES/1244 (1999), available at: http://www.refworld.org/docid/3b00f27216.html [accessed 15 
January 2016]

${ }^{58}$ Carley, Patricia. Preface. SELF-DETERMINATION Sovereignty, Territorial Integrity, and the Right to Secession. Washington, DC (1550 M St., NW, Suite 700, Washington 20005-1708):

U.S. Institute of Peace, 1996. 3. Print.

${ }^{59}$ Friedrich, pp. 239

${ }^{60}$ Ibid.

${ }^{61}$ Ibid.

62 Ibid.

63 Ibid.

${ }^{64}$ Scheye, Eric. "UNMIK and the Significance of Effective Programme Management: The Case of Kosovo." Security Sector Reform and UN Integrated Missions: Experience from Burundi, the Democratic Republic of Congo, Haiti and Kosovo. By Heiner Hänggi and Vincenza Scherrer. Berlin: Lit, 2008. 171. Print. ${ }^{65}$ Ibid.

${ }^{66}$ United Nations, Charter of the United Nations, 24 October 1945, 1 UNTS XVI, available at: http://www.refworld.org/docid/3ae6b3930.html [accessed 22 January 2016] 67 "Office of The Special Adviser on The Prevention of Genocide." UN News Center. United Nations, n.d. Web. 16 Jan. 2016.

68 "Kofi Annan Biography." Bio.com. A\&E Networks Television, n.d. Web. 16 Jan. 2016.

${ }^{69}$ Côté-Harper, Gisèle, Lee Hamilton, Michael Ignatieff, Vladimir Lukin, Klaus Naumann, Cyril Ramaphosa, Fidel Ramos, Cornelio Sommaruga, Eduardo Stein, and Ramesh Thakur. "The Responsibility to Protect." Responsibility to Protect (2001): VII.

Responsibilitytoprotect.org. International Development Research Centre, Dec. 2001. Web. 
12 Feb. 2016.

${ }^{70}$ Marjanovic, Mario. "Is Humanitarian War the Exception?" Mises Institute Austrian Economics, Freedom and Peace. Mises Institute, 4 Apr. 2011. Web. 4 Feb. 2016.

${ }^{71}$ Scheffer, David J. “Towards a Modern Doctrine of Humanitarian Intervention." University of Toledo Law Review Vol 23. (1992): 253-274.

72 "Repertoire of the Practice of the Security Council." UN News Center. United Nations, n.d. Web. 24 Jan. 2016.

${ }^{73}$ United Nations, Charter of the United Nations Chapter VII, 24 October 1945, 1 UNTS XVI, available at: http://www.refworld.org/docid/3ae6b3930.html [accessed 22 January 2016]

${ }^{74}$ GSDRC (2013). International legal frameworks for humanitarian action: Topic guide. Birmingham, UK: GSDRC, University of Birmingham 75 "NATO's Role in Relation to the Conflict in Kosovo." NATO \& Kosovo: Historical Overview. NATO, 15 July 1999. Web. 13 Jan. 2016.

${ }^{76}$ Ibid.

${ }^{77}$ Ibid.

${ }^{78}$ Adam Roberts (1999) NATO's 'Humanitarian War' over Kosovo, Survival, 41:3, pp 102, DOI: $10.1080 / 00396339912331342943$

${ }^{79}$ Ristic, Marija. "Death Toll From NATO Yugoslavia Bombing Still Unknown." Balkan Insight. Balkan Investigative Reporting Network, 25 Mar. 2013. Web. 28 Jan. 2016. 80 "The North Atlantic Treaty." NATO. NATO, 4 Apr. 1949. Web. 17 Jan. 2016. 81 United Nations, Charter of the United Nations, 24 October 1945, 1 UNTS XVI, available at: http://www.refworld.org/docid/3ae6b3930.html [accessed 22 January 2016] 
${ }^{82}$ The Universal Declaration of Human Rights. Rep. N.p.: United Nations, 1948. UN News Center. United Nations. Web. 18 Jan. 2016.

${ }^{83}$ Ibid.

${ }^{84}$ UN Security Council, Security Council resolution 1244 (1999) [on the deployment of international civil and security presences in Kosovo], 10 June 1999, S/RES/1244 (1999), available at: http://www.refworld.org/docid/3b00f27216.html [accessed 15 January 2016] 85 Ibid.

86 Independent International Commission on Kosovo (2000).The Kosovo Report: Conflict, International Response, Lessons Learned. Pp 8. Oxford University Press. ISBN 978-0-19924308-2. Accessed on 17 Nov. 2015

${ }^{87}$ Friedrich, pp 244

${ }^{88}$ Cabrera, Luis G. Global Governance, Global Government: Institutional Visions for an Evolving World System. N.p.: State U of New York, 2011. pp 214. Print. ${ }^{89}$ UN Security Council, Rambouillet Accords (1999) [Interim Agreement for Peace and SelfGovernment in Kosovo], 7 June 1999, S/1999/648 (1999), available at: http://peacemaker.un.org/sites/peacemaker.un.org/files/990123_RambouilletAccord.pdf [accessed 11 January 2016]

90 Ibid.

${ }^{91}$ Ibid.

92 Ibid.

${ }^{93}$ Krasniqi, Jakup, and Republic of Kosovo Assembly. "Kosovo Declaration of Independence." Republic of Kosovo. N.p., 17 Feb. 2008. Web. 14 Jan. 2016. 
94 Ibid.

${ }^{95}$ Rice, Condoleezza. "U.S. Recognizes Kosovo as Independent State." U.S. Recognizes Kosovo as Independent State. US Department of State, 18 Feb. 2008. Web. 14 Jan. 2016. 96 "Countries That Have Recognized The Republic Of Kosovo." Ministry of Foreign Affairs. Ministry of Foreign Affairs - Republic of Kosovo, n.d. Web. 13 Jan. 2016. 97 "Serbia to Go to ICJ over Kosovo - on B92" B92.net. N.p., 26 Mar. 2008. Web. 12 Feb. 2016. 98 "The Court." International Court of Justice. International Court of Justice, n.d. Web. 12 Feb. 2016.

${ }^{99}$ Accordance with International Law of the Unilateral Declaration of Independence in Respect of Kosovo (Request for Advisory Opinion), General List No. 141, International Court of Justice (ICJ), 22 July 2010, available at:

http://www.refworld.org/docid/4c5151002.html [accessed 13 February 2016] 100 Verbatim Record of Kosovo Representation of the Accordance with International Law of the Unilateral Declaration of Independence by the Provisional Institutions of SelfGovernment of Kosovo. ICJ.org 12. International Court of Justice. 22 July 2010. Web. 101 Ibid. pp. 13

102 Ibid. pp. 14

103 Ibid. pp. 8-9

${ }^{104}$ Constitution of the Republic of Serbia [Serbia], 30 September 2006, pp. 34 available at: http://www.refworld.org/docid/4b5579202.html [accessed 23 February 2016] 105 Verbatim Record of Serbia Representation of the Accordance with International Law of the Unilateral Declaration of Independence by the Provisional Institutions of SelfGovernment of Kosovo. ICJ.org 13. International Court of Justice. 22 July 2010. Web. 
106 Ibid. pp. 14

107 "Kosovo MPs Proclaim Independence." BBC News. BBC, 17 Feb. 2008. Web. 13 Feb. 2016. 108 Verbatim Record of Albania Representation of the Accordance with International Law of the Unilateral Declaration of Independence by the Provisional Institutions of SelfGovernment of Kosovo. ICJ.org 14-17. International Court of Justice. 22 July 2010. Web. ${ }^{109}$ Hsu, Jenny. "Taiwan Officially Recognizes Kosovo, James Huang Says - Taipei Times." Taiwan News. Taipei Times, 20 Feb. 2008. Web. 13 Feb. 2016.

110 Ibid. to ICJ Advisory Opinion.

111 "Kosovo Independence Declaration Deemed Legal." Reuters. Ed. Philippa Fletcher. Thomson Reuters, 22 July 2010. Web. 13 Feb. 2016.

112 Ibid. to ICJ Advisory Opinion. Pp. 52

${ }^{113}$ Accordance with International Law of the Unilateral Declaration of Independence in Respect of Kosovo (Request for Advisory Opinion), Vice President Tomka Declaration, International Court of Justice (ICJ), 22 July 2010 pp 55 114 Ibid. pp 56-57 115 Accordance with International Law of the Unilateral Declaration of Independence in Respect of Kosovo (Request for Advisory Opinion), Judge Koroma Dissenting Opinion, International Court of Justice (ICJ), 22 July 2010 pp 68 116 Ibid. pp 70 